\title{
Genetic Analysis of Variation for Yield and Related Traits in the Ricebean Germplasm (Vigna umbellata (thunb.) ohwi and ohashi) of NW Himalayas
}

\author{
Neelam Bhardwaj* and Sanchit Thakur
}

Department of Organic Agriculture, CSKHPKV, Palampur, Himachal Pradesh-176062, India

\author{
*Corresponding author
}

\author{
A B S T R A C T
}

\begin{tabular}{|l|}
\hline K e y w o r d s \\
Genetic analysis, \\
$\begin{array}{l}\text { Variation for yield, } \\
\text { Traits, Ricebean, } \\
\text { Himalayas. }\end{array}$ \\
\hline Article Info \\
\hline $\begin{array}{l}\text { Accepted: } \\
\text { 04 September } 2017 \\
\text { Available Online: } \\
\text { 10 November } 2017\end{array}$
\end{tabular}

The present investigation was carried out to estimate different genetic parameters in ricebean germplasm of NW Himalayas. Forty germplasm lines of rice bean were evaluated for yield and its components in Kharif, 2015 at the experimental farm of CSKHPKV, Palampur. High PCV and GCV was observed for seed yield/plant, plant height, pod length, pods/cluster and clusters/plant indicating the role of these characters for effective selection. The study also revealed that heritability in broad sense was high for days to flowering, plant height and pods/cluster indicating that the variation observed was mostly under genetic control and less influenced by environment. Overall high to moderate heritability with high genetic advance was observed for plant height and seed yield/plant indicating additive gene control of these traits. On the basis of mean performance the genotypes, RBHP-403, RBHP-43, RBHP-413, UURB-17, IC-419518, IC-395028 were found promising among all the germplasm lines. The genotype PRR-2007-2 was observed to be earliest and dwarfest genotype among all.

\section{Introduction}

Ricebean is a multipurpose grain legume crop mainly cultivated for food, fodder and green manure specifically by the poor farmers in the marginal areas of South Asia and South East Asia. It is mainly cultivated in India, China, Korea, Japan, Myanmar, Malaysia, Indonesia, Philippines, Java, Fiji, Bangladesh, Sri Lanka and Nepal. It is an important crop of Mid Himalayan region. In India its distribution is mainly confined to the tribal region of the North-eastern hills and the western and Eastern Ghats in peninsular region, often in hilly tracts. However its cultivation and production is limited and restricted to small and marginal areas. Therefore ricebean is regarded as underutilized crop.
This underutilized crop has recently gained attention as an additional grain legume/pulse crop which keeps great potential to solve the food and nutritional problem. Since resource poor farmers in the marginal areas cultivate this crop, therefore it is directly related with the population who really suffers frequent food shortage and nutritional disorders.

Mostly it is cultivated on the non-irrigated and uncultivated lands which otherwise goes waste, hence cultivation of ricebean in such areas is considered important contribution to food and nutritional security and to utilize uncultivated marginal land and conserving biodiversity. The potential productivity of 
ricebean has been found superior over other pulse crops, such as greengram and blackgram in mid altitude, particularly Himalayan region, beyond $1500 \mathrm{~m}$ above mean sea level where other pulse crops like blackgram and green gram cannot be grown successfully. However, under these conditions, ricebean gives reasonably good seed yield because of its better cold tolerance ability and better adaptation to acidic soil condition (Dutta et al., 2000 and Shukla et al., 2014).

The nutritive value of ricebean is exceptionally high. The protein contents of seeds vary from $14-24 \%$ and the amino acids, methionine and tryptophane are considerable high. It provides sizable amounts of important minerals such as $\mathrm{Ca}, \mathrm{P}, \mathrm{Mg}, \mathrm{K}, \mathrm{Fe}, \mathrm{Zn}, \mathrm{Cu}$ and $\mathrm{Mn}$.

This crop has been left as a neglected one due to lack of attention and absence of any kind of scientific breeding. Although it's nutritional quality and other associated benefits qualifies this crop for intensive research, and development efforts for increased and sustained production.

However, little research work on its qualities can enhance its properties according to our requirements and this crop which is highly adaptive to all sorts of marginal areas and soils can rise as a great source of edible nutrients for the poor people residing in those areas. For the effective selection of superior genotype to use in hybridization programme for the development of superior varieties, proper study of genetic variability due to genetic and non-genetic causes and other genetic parameters is necessary (Prasad et al., 2012). So, the main objective of present investigation was to estimate the genetic variability, heritability, and genetic advance for different important economic characters in a set of diverse genotypes of ricebean.

\section{Materials and Methods}

The experimental material for the present study consisted of 38 ricebean germplasm lines and two checks namely PRR-1 and PRR-2. These genotypes along with checks were evaluated for different qualitative and quantitative traits in RBD design during kharif, 2015 with plot size of $3 \mathrm{~m} \times 0.6 \mathrm{~m}$ with row to row and plant to plant distance of $30 \mathrm{~cm}$ and $10 \mathrm{~cm}$, respectively in 3 replications at the experimental farm of the Department of Organic agriculture, CSKHPKV, Palampur. The crop was raised following recommended package of practices.

Observations were recorded on 10 randomly selected plants for days to flowering and maturity, plant height $(\mathrm{cm})$, branches/plant, pods/plant, pod length, pod width $(\mathrm{cm})$, seeds / pod,100-seed weight $(\mathrm{g})$ and seed yield/plant. The mean values were used for statistical analysis. Analysis of variance was done according to procedure given by Panse and Sukhatme (1987). The genotypic, phenotypic and environmental coefficients of variation were estimated by following method of Burton and DeVane (1958). Heritability in broad sense was calculated by the formula given by Burton and DeVane (1958) and Johnson (1955). The estimates of genetic advance were obtained by the formula given by Burton and DeVane (1958) and Johnson (1955).

\section{Results and Discussion}

Perusal of the data on analysis of variance (ANOVA) revealed significant differences among the genotypes for seed yield and related traits indicating presence of sufficient variability for all the traits except pods/plant and seeds/pod. The estimate of genotypic and phenotypic coefficient of variation provides a better comparison of the characters for the estimation of genetic variation. The 
knowledge of phenotypic coefficient of variation $(\mathrm{PCV})$ and genotypic coefficient of variation $(\mathrm{GCV})$ is helpful in predicting the amount of variation present in the given stock which in turn helps in formulating an efficient breeding programme. The estimates of phenotypic coefficient of variation (PCV), genotypic coefficient of variation (GCV), heritability and genetic advance are presented in Table 1.

An assessment of variability parameters revealed presence of sufficient variation among the genotypes. In general, values of phenotypic coefficient of variation (PCV) were higher than their respective genotypic coefficient of variation (GCV) indicating considerable influence of environment on the performance of genotypes. High PCV (>15\%) was observed for seed yield/plant, clusters/plant, pods/plant, plant height, pod length and pods/cluster.

Moderate PCV (10-15\%) was observed for seeds/pod, 100-seed weight, branches/plant, days to maturity and low PCV $(<10 \%)$ was observed for days to flowering. High GCV (>10\%) was observed for seed yield/plant, plant height, clusters/plant, pods/cluster and pod length.

Moderate GCV (5-10\%) was observed for days to flowering, 100-seed weight, days to maturity, pods/plant and branches/plant while low GCV (<5\%) was observed for seeds/pod. Studies with similar research findings were carried out by various workers (Lakshmana $e t$ al., 2010, Gill and Brar, 2007) (Table 2).

When a major portion of variability is due to heritable variation it could be measured in terms of degrees in which it is transmitted to the progeny, the term referred to as heritability. Burton and DeVane (1958) has suggested that a genetic coefficient of variability together with the heritability estimates would give the more reliable indication of the expected genetic gain by selection. Heritability in broad sense is of tremendous significance to the breeders as its magnitude indicates reliability with which a genotype can be recognized by its phenotypic expression.

The information on heritability estimates is useful in studying the inheritance of quantitative traits as well as for planning breeding programmes with desired degree of expected genetic progress. The present study revealed that heritability in broad sense was high $(>60 \%)$ for only some traits studied viz., days to flowering, plant height and pods/cluster indicating that the genetic variance for these traits are probably owing to their high additive gene effects and thus there is better scope for improvement of these traits through direct selection.

Moderate heritability (40-60\%) was observed for days to maturity, seed yield/plant, branches/plant, 100-seed weight, pod length, and clusters/plant whereas low heritability $(<40 \%)$ was observed for pods/plant and seeds/pod. High and moderate heritability values of these traits indicated that the variation observed was mainly under genetic control and less influenced by environment. Plant height, pods/cluster and seed yield/plant show high GCV and heritability, hence can be considered for selection.

Similar results were reported by different workers in ricebean. Lakshmana et al., (2010) observed high heritability coupled with high genetic advance for days to flowering, number of seeds/pod, number of pods/plant, seed yield/plant and harvest index.

Similarly, Dash (2012) observed high heritability estimate for days to flowering, branches/plant, branch length, leaf weight and dry matter/plant. 
For categorizing the magnitude of different parameters, the following limits were used

$\begin{array}{lrl}\text { PCV } & >15 \% & \text { High } \\ & 10-15 \% & \text { Moderate } \\ \text { GCV \&ECV } & <10 \% & \text { Low } \\ & >10 \% & \text { High } \\ & 5-10 \% & \text { Moderate } \\ \text { Heritability }\left(\mathbf{h}^{2}{ }_{\text {bs }}\right) & <5 \% & \text { Low } \\ & >60 \% & \text { High } \\ & 40-60 \% & \text { Moderate } \\ \text { Genetic advance } & <40 \% & \text { Low } \\ & >20 \% & \text { High } \\ & 10-20 \% & \text { Moderate } \\ & <10 \% & \text { Low }\end{array}$

Table.1 Analysis of variance for different traits

\begin{tabular}{|l|c|c|c|}
\hline Character & \multicolumn{3}{|c|}{ Mean sum of square } \\
\hline De & Replication & Treatment & Error \\
\hline Days to flowering & 2 & 39 & 78 \\
\hline Days to maturity & 76.03 & $173.39^{*}$ & 16.71 \\
\hline Plant height & 309.20 & $434.21^{*}$ & 79.20 \\
\hline Branches/plant & 0.01 & $1,544.87^{*}$ & 162.57 \\
\hline Pods/plant & 324.02 & $0.07^{*}$ & 0.03 \\
\hline Pod length & 2.40 & 201.05 & 131.91 \\
\hline 100- seed weight & 1.73 & $4.62^{*}$ & 1.25 \\
\hline Seeds/pod & 1.17 & $2.60^{*}$ & 0.69 \\
\hline Clusters/pod & 0.73 & 1.86 & 1.36 \\
\hline Pods/cluster & 0.09 & $34.62^{*}$ & 9.58 \\
\hline Seed yield/plant & 1.81 & $0.49^{*}$ & 0.09 \\
\hline
\end{tabular}

*Significant at $5 \%$ level of significance

Table.2 Estimates of parameters of variability for various traits

\begin{tabular}{|l|c|c|c|c|c|c|c|}
\hline Traits & $\begin{array}{c}\text { Mean } \mathbf{\pm S} \\
\mathbf{E}(\mathbf{m})\end{array}$ & Range & $\begin{array}{c}\text { PCV } \\
(\mathbf{\%})\end{array}$ & $\begin{array}{c}\text { GCV } \\
(\mathbf{\%})\end{array}$ & $\begin{array}{c}\text { ECV } \\
(\boldsymbol{\%})\end{array}$ & $\begin{array}{c}\text { Heritability } \\
\mathbf{h}^{2} \mathbf{b s} \mathbf{( \% )}\end{array}$ & $\begin{array}{c}\text { Expected } \\
\text { GA }\end{array}$ \\
\hline $\begin{array}{l}\text { Days to } \\
\text { flowering }\end{array}$ & 84.89 & $52-96$ & 9.78 & 8.51 & 4.82 & 75.76 & 15.26 \\
\hline $\begin{array}{l}\text { Days to } \\
\text { maturity }\end{array}$ & 131.64 & $106-152$ & 10.68 & 8.26 & 6.76 & 59.91 & 13.18 \\
\hline Plant height & 152.48 & $90-176.27$ & 16.37 & 14.08 & 8.36 & 73.92 & 24.93 \\
\hline $\begin{array}{l}\text { Branches/ } \\
\text { plant }\end{array}$ & 1.88 & $1.53-2.16$ & 10.80 & 6.16 & 8.87 & 32.54 & 7.24 \\
\hline Pods/plant & 68.23 & $39.1-80$ & 18.24 & 7.04 & 16.83 & 14.87 & 5.59 \\
\hline Pod length & 9.65 & $5.95-11.68$ & 15.96 & 10.20 & 11.57 & 47.49 & 15.61 \\
\hline $\begin{array}{l}\text { 100-seed } \\
\text { weight }\end{array}$ & 9.61 & $6.83-11.69$ & 11.99 & 8.30 & 8.65 & 47.96 & 11.85 \\
\hline Seeds /pod & 9.15 & $6.06-10.43$ & 13.49 & 4.48 & 12.73 & 11.04 & 3.07 \\
\hline Clusters/plant & 22.38 & $11.8-28.96$ & 18.92 & 12.91 & 13.84 & 46.55 & 18.14 \\
\hline Pods/cluster & 2.99 & $2.06-3.53$ & 15.63 & 12.18 & 9.80 & 60.69 & 19.55 \\
\hline $\begin{array}{l}\text { Seed } \\
\text { yield/plant }\end{array}$ & 9.93 & $3.44-12.45$ & 20.36 & 15.03 & 13.73 & 54.51 & 22.87 \\
\hline
\end{tabular}


Table.3 Mean performance of rice bean genotypes

\begin{tabular}{|c|c|c|c|c|c|c|c|c|c|c|c|}
\hline Lines & $\begin{array}{l}\text { Days to } \\
\text { flowering }\end{array}$ & $\begin{array}{l}\text { Days to } \\
\text { maturity }\end{array}$ & $\begin{array}{l}\text { Plant } \\
\text { Height }\end{array}$ & $\begin{array}{l}\text { Branche } \\
\text { s/plant }\end{array}$ & $\begin{array}{l}\text { Pods/ } \\
\text { plant }\end{array}$ & $\begin{array}{l}\text { Pod } \\
\text { length }\end{array}$ & $\begin{array}{l}\text { 100-seed } \\
\text { weight }\end{array}$ & $\begin{array}{l}\text { Seeds/ } \\
\text { pod }\end{array}$ & $\begin{array}{l}\text { Cluster } \\
\text { s/plant }\end{array}$ & $\begin{array}{l}\text { Pods/c } \\
\text { luster }\end{array}$ & $\begin{array}{l}\text { Seed } \\
\text { yield/plant }\end{array}$ \\
\hline LRB-478 & 88.00 & 147.33 & 157.83 & 2.00 & 80.00 & 10.11 & 9.66 & 9.43 & 24.03 & 3.50 & 11.07 \\
\hline LRB-474 & 83.00 & 127.00 & 155.38 & 1.90 & 67.99 & 10.14 & 9.59 & 9.07 & 22.60 & 3.13 & 11.03 \\
\hline LRB-473 & 88.00 & 129.00 & 169.87 & 1.80 & 76.40 & 10.72 & 10.30 & 9.37 & 15.60 & 2.07 & 7.60 \\
\hline LRB-476 & 83.00 & 133.00 & 158.51 & 2.00 & 76.87 & 9.83 & 9.93 & 9.23 & 22.27 & 3.10 & 10.93 \\
\hline LRB-449 & 91.33 & 151.67 & 163.18 & 2.00 & 78.87 & 10.17 & 9.55 & 9.47 & 19.50 & 2.33 & 9.10 \\
\hline LRB-447 & 85.00 & 142.67 & 171.27 & 1.90 & 71.53 & 10.79 & 9.39 & 9.23 & 28.97 & 3.20 & 10.74 \\
\hline LRB-475 & 83.33 & 135.67 & 158.19 & 1.93 & 67.40 & 8.05 & 8.93 & 8.83 & 17.47 & 2.47 & 10.17 \\
\hline LRB-464 & 90.67 & 134.00 & 164.65 & 1.87 & 68.80 & 9.64 & 8.33 & 9.17 & 23.60 & 3.37 & 9.88 \\
\hline LRB-311 & 89.00 & 148.67 & 174.44 & 2.17 & 58.67 & 8.78 & 9.74 & 9.40 & 20.80 & 2.77 & 9.58 \\
\hline LRB-498 & 89.66 & 138.67 & 172.78 & 1.67 & 68.67 & 10.13 & 9.60 & 8.67 & 23.73 & 2.40 & 10.76 \\
\hline LRB-455 & 82.33 & 136.67 & 161.94 & 1.87 & 72.87 & 9.19 & 8.77 & 9.37 & 23.43 & 3.33 & 11.61 \\
\hline IC-395028 & 90.00 & 135.33 & 170.79 & 2.10 & 66.07 & 10.55 & 10.04 & 9.60 & 24.00 & 3.50 & 11.73 \\
\hline IC-538878 & 91.33 & 138.33 & 165.10 & 1.90 & 74.20 & 11.26 & 9.78 & 9.87 & 25.47 & 3.27 & 10.37 \\
\hline IC-23512 & 96.00 & 139.00 & 176.27 & 1.80 & 67.40 & 10.11 & 11.70 & 9.77 & 19.93 & 2.70 & 8.29 \\
\hline IC-538983 & 88.00 & 131.67 & 169.82 & 2.03 & 59.20 & 10.43 & 11.18 & 8.87 & 23.80 & 2.97 & 9.22 \\
\hline IC-419518 & 84.00 & 142.67 & 173.92 & 1.70 & 75.40 & 11.69 & 11.61 & 10.43 & 25.77 & 3.17 & 12.10 \\
\hline IC-359282 & 90.67 & 138.33 & 167.55 & 1.87 & 68.27 & 10.49 & 10.15 & 8.97 & 19.23 & 3.20 & 9.41 \\
\hline IC-524082 & 90.00 & 132.67 & 169.62 & 1.90 & 69.47 & 10.52 & 9.37 & 8.50 & 23.70 & 2.33 & 9.06 \\
\hline IC-421926 & 87.33 & 142.33 & 168.51 & 1.60 & 59.67 & 10.03 & 9.72 & 9.20 & 22.73 & 3.27 & 10.85 \\
\hline IC-538870 & 88.67 & 152.00 & 165.72 & 2.07 & 65.33 & 8.20 & 9.40 & 9.17 & 24.27 & 2.10 & 9.00 \\
\hline UURB-17 & 91.00 & 145.00 & 159.64 & 2.10 & 75.27 & 11.63 & 10.44 & 9.87 & 24.00 & 3.23 & 11.42 \\
\hline UURB-2014-I & 79.33 & 134.33 & 173.23 & 1.77 & 75.53 & 10.09 & 9.52 & 9.57 & 24.33 & 2.70 & 9.97 \\
\hline PRR-2007-2 & 52.00 & 106.00 & 90.00 & 1.70 & 39.10 & 5.95 & 7.26 & 6.06 & 11.80 & 2.13 & 3.44 \\
\hline RBHP-401 & 96.00 & 112.33 & 98.00 & 1.90 & 43.09 & 6.67 & 6.83 & 7.00 & 14.97 & 2.73 & 5.76 \\
\hline RBHP-43 & 88.33 & 128.67 & 151.17 & 2.13 & 75.67 & 10.95 & 10.75 & 10.43 & 20.27 & 3.33 & 11.71 \\
\hline RBHP-38 & 87.00 & 140.33 & 149.00 & 1.93 & 64.73 & 9.39 & 9.96 & 8.93 & 18.13 & 3.07 & 9.62 \\
\hline RBHP-403 & 82.33 & 111.67 & 108.33 & 2.07 & 69.00 & 8.69 & 10.45 & 9.57 & 26.33 & 3.00 & 12.45 \\
\hline RBHP-404 & 81.33 & 115.33 & 108.33 & 1.77 & 73.00 & 8.39 & 9.06 & 8.83 & 23.53 & 3.00 & 9.60 \\
\hline RBHP-405 & 74.33 & 115.00 & 126.67 & 1.97 & 77.67 & 10.34 & 9.66 & 9.13 & 25.40 & 3.13 & 10.87 \\
\hline RBHP-406 & 81.33 & 114.33 & 140.67 & 1.70 & 73.53 & 9.39 & 9.22 & 9.13 & 23.33 & 3.03 & 11.12 \\
\hline RBHP-407 & 91.00 & 123.33 & 149.76 & 1.87 & 62.93 & 8.42 & 8.91 & 8.73 & 24.43 & 3.00 & 10.19 \\
\hline RBHP-408 & 77.00 & 118.33 & 139.85 & 1.90 & 67.67 & 8.33 & 8.98 & 8.67 & 24.33 & 3.37 & 9.05 \\
\hline RBHP-409 & 88.00 & 123.00 & 149.72 & 1.67 & 68.40 & 9.75 & 9.08 & 8.77 & 24.57 & 3.53 & 10.60 \\
\hline RBHP-410 & 81.33 & 120.00 & 116.67 & 1.96 & 67.67 & 9.97 & 9.15 & 8.40 & 23.73 & 3.07 & 8.36 \\
\hline RBHP-411 & 71.67 & 114.00 & 113.33 & 1.53 & 67.33 & 8.21 & 10.10 & 8.83 & 22.90 & 3.23 & 10.73 \\
\hline RBHP-412 & 79.67 & 130.00 & 154.20 & 1.83 & 69.67 & 8.88 & 9.48 & 10.37 & 23.53 & 3.33 & 9.573 \\
\hline RBHP-413 & 79.33 & 126.33 & 147.08 & 1.90 & 66.27 & 11.03 & 9.88 & 9.80 & 26.70 & 3.33 & 11.447 \\
\hline RBHP-414 & 89.33 & 125.33 & 160.45 & 1.90 & 65.27 & 8.77 & 9.21 & 9.60 & 22.33 & 2.87 & 8.880 \\
\hline PRR-I (C) & 81.00 & 139.67 & 162.12 & 1.80 & 67.67 & 9.65 & 9.39 & 9.27 & 19.70 & 3.17 & 10.820 \\
\hline PRR-2 (C) & 85.00 & 146.00 & 164.68 & 1.67 & 66.80 & 10.59 & 10.31 & 9.47 & 19.80 & 3.27 & 9.100 \\
\hline $\mathrm{CD}$ & 6.64 & 14.47 & 20.72 & 0.27 & NS & 1.81 & 1.35 & NS & 5.032 & 0.48 & 2.2175 \\
\hline
\end{tabular}


For an effective selection programme, knowledge of the estimates of heritability alone is not sufficient and genetic advance if studied along with heritability is more useful (Johnson et al., 1955). Thus, the genetic advance has an added edge over heritability as a guiding factor to breeders in various selection programmes. Genetic advance may and may not be in proportion to genetic variability and heritability estimates, because both heritability and high genetic variability are important to obtain higher genetic gain. Genetic advance expressed as percentage of mean was observed to be low $(<10 \%)$ for seeds/pod, pods/plant and branches/plant. It was high $(>20 \%)$ for plant height and seed yield/plant while moderate genetic advance (10-20\%) was observed for pods/cluster, clusters/plant, pod length, days to flowering, days to maturity and 100-seed weight. For predicting reliable estimates of additive and non-additive effects, heritability should be considered in conjugation with genetic advance. On this consideration, high heritability with high genetic advance was found only for plant height indicating the presence of high additive gene effects providing scope for improvement of the trait through selection. High heritability with moderate genetic advance was observed for days to flowering and pods/cluster indicating presence of additive and non-additive gene action in the inheritance of these traits, providing scope for improvement of these traits through hybridization and selection. Moderate heritability coupled with high genetic advance for seed yield/plant indicated the additive genetic control of this trait and further, selection would be effective on the basis of phenotype. The mean performance of the genoytpes in respect of characters investigated in the present study is presented in Table 3. The germplasm line PRR-2007-2 was found earliest among all taking 52 days to flower and 106 days to mature. Eleven lines were earlier in maturity to the best check i.e. PRR-1. Line PRR-2007-2 was having lowest value of plant height $(90 \mathrm{~cm})$ among all the lines under study. Since most of the ricbean varieties are late maturing and indeterminate, this line will be of immense importance to the breeders for future breeding programmes for the improvement of this crop. Four lines viz., LRB 311, RBHP-43, UURB17 and IC-395028 were found to be superior for branches per plant over the best check PRR-1. None of the genotype was found superior to the best check for pod length and pods per cluster whereas one germplasm line IC-23512 was found to be superior to the best check for 100-seed weight. Among all, LRB447 exhibited highest clusters/plant followed by RBHP-413, RBHP-403, IC-419548, IC538878, RBHP-405 and RBHP-409. RBHP403 was the highest yielder followed by IC419518， IC-395028， RBHP-43，LRB-455, RBHP-413, UURB-17 and LRB-498. On the basis of mean performance of all the genotypes, RBHP-403, RBHP-43, RBHP413, UURB-17, IC-419518, IC-395028 was found promising among all the germplasm lines. The genotype PRR-2007-2 was earliest and dwarfest genotype among all so it can be used as a potential parent for the incorporation of earliness and determinate habit which is major bottleneck in the popularization of this crop.

\section{References}

Burton, G.M., and DeVane E.H. 1958. Estimating heritability in tall Fescue (Festuca arundinacea) from replicated colonal material. Agronomy Journal 45: 310-314

Dash, G.B., 2012. Variability and character association studies among micromutants of forage ricebean. Forage Research 38: 119-121

Dutta, M., Dutta A., Prasad, R. and Bandyopadhyay B. 2000. Ricebean- a potential underutilized grain legume for 
the hills. Indian Farming. 50 (5): 25-29.

Gill, R.K., and Brar G.S. 2007. Assessment of variation and co-variation for yield and its components in ricebean germplasm. Agricultural Research Journal 44: 365368

Johnson, H.M., Robinson H.F. and Comstock R.E. 1955. Estimates of genetic and environmental variability in soybeans. Agronomy journal. 47: 314-318.

Lakshmana, D., Jolli R.B. and Madaiah D. 2010. An investigation was carried out to estimate the genetic parameters for twelve traits in ricebean genotypes. Legume Research 33: 279 - 282

Panse, V.G., and Sukhatme P.V. 1987.
Statistical methods for agricultural workers. Indian Council of Agricultural Research, New Delhi

Prasad, B., Bahuguna A. and Shukla D.K. 2012. Genotypic variation studies of perilla (Perilla prutescens L.) germplasm under North-West Himalayan agrisystem. Environment and Ecology, 30(4): 1235-1237.

Shukla, D.K., Pratap T. and Prasad B. 2014. Standardization of organic manure levels for better growth, yield an economics of ricebean (Vigna umbellata L.) under central Himalaya. Journal of Hill Agriculture 5(1): 57-60.

\section{How to cite this article:}

Neelam Bhardwaj and Sanchit Thakur. 2017. Genetic Analysis of Variation for Yield and Related Traits in the Ricebean Germplasm [Vigna umbellata (thunb.) ohwi and ohashi] of NW Himalayas. Int.J.Curr.Microbiol.App.Sci. 6(11): 125-131.

doi: https://doi.org/10.20546/ijcmas.2017.611.016 